\title{
カンキツ果実におけるチャノキイロアザミウマの 密度と被害との関係
}

\author{
多々良明夫1)・古橋 嘉一 \\ 静岡県柑橘試験場
}

\begin{abstract}
Analytical Study on Damage to Satsuma Mandarin Fruit by Scirtothrips dorsalis Hood (Thysanoptera: Thripidae), with Particular Reference to Pest Density. Akio Tatara ${ }^{2)}$ and Kaichi Furuhashi (Shizuoka Gitrus Experiment Station, Shimizu, Shizuoka 424, Japan). Jpn. J. Appl. Entomol. Zool. 36: 217-223 (1992)

The relationship between the density of $S$. dorsalis on satsuma mandarin fruit and damage at harvest was analyzed from investigations in 12 mandarin groves in Shimizu, Shizuoka Prefecture during 1984-1988. Damage to the pedicel of fruits started to appear in early June and was maximum in early August. Silver-scar damage to the stylar end of fruits appeared from mid- August and was maximum at mid-September. Based on regression analysis of the damage to larval density, damage to the pedicel at harvest is related to the maximum larval density during the infestation period. However, no relationship was detected between damage to the stylar end and maximum larval density. The economic threshold for the fruit pedicel was calculated to be $8.0 \%$ expressed as a ratio of sampled fruits in which the larvae were found from early June to late July. The larvae were more aggregated than the adults within a tree and between trees.
\end{abstract}

Key words: Scirtothrips dorsalis, damage, citrus, spatial distribution, economic threshold

緒

言

チャノキイロアザミウマは日本のほか, 東南アジア, オーストラリアなどに広く分布し，それらの地域ではチ ヤ, トウガラシなどの害虫として知られている (MOUND and Palmer, 1981)。日本ではカンキツのほかにチャ, ブドウ，カキなどの重要害虫となっている。カンキッへ の加害は 1967 年ごろより静岡県において問題となり始 め (西野，1972)，現在ではほとんどのカンキツ産地で重 要害虫の一つになっている。

本種は寄主植物が多く, 28 科 50 種の植物に対する加 害が認められている(村岡，1988)。それらのなかでカン キッ園に拈计る密度はチャ, イヌマキの $5 \%$ 程度と非常 に低い(多々良・古橋, 1986)。しかし, 本種はカンキッ の新葉と果実を加害し，果実の商品性低下に与える影響 がきわめて大きい。

本種によるカンキッの果実への加害様式は, 本種の口 針の長さが $10 \mu \mathrm{m}$ 以下であるため (高木, 1981), 加害
されるカンキッ果実の果皮細胞は表皮細胞に限られる。 吸汁された表皮細胞は乾燥し，果実の肥大に伴ってひび 割れが生じ; さらに拡大して癒傷組織が形成され，肉眼 では灰色の薄膜ができたように見える。

このように，チャノキイロアザミウマは食物が表皮細 胞に限られることから, 果実の広い面積から吸汁し，そ の結果, カンキッでは低密度にもかかわらず大きな被害 をもたらす原因となっている。このため, 正確な密度推 定，それに伴う防除要否が困難なのが現状である。

今回, 5 年間延べ 12 のカンキツ園に拉ける密度およ び被害調査の結果から, チャノキイロアザミウマの加害 習性および果実上の個体数と被害との関係およびカンキ ツ園における分布特性を検討し，それらに基ついて被害 果率による要防除水準の設定を試みたので報告する。

本文に入る先立ち, 本稿の校閲を賜わった農林水産省 農業環境技術研究所・矢野栄二博士，報文をまとめるに あたり助言をいただいた大阪府立大学農学部・森内茂博 士に深謝の意を表する。

1) 現在 静岡県西部病害虫防除所

2) Present address: Shizuoka Seibu Plant Protection Office, Higashi-tamachi, Hamamatsu, Shizuoka 430, Japan. 1991 年 9 月 3 日受領 (Received 3 September 1991) 1992 年 6 月 6 日登載決定 (Accepted 6 July 1992) 


\section{調 查 方 法}

調査は $1984 〜 1988$ 年にわたり静岡県清水市日本平の 温州ミカン栽培地で行った。

1984１986 年の3 年間には調査注場として青島温州 $10 \mathrm{a}$ ，興津早生 $10 \mathrm{a}$ を選えだ。そのらち青島温州園はほ ぼ無防除で, 植栽本数は 53 樹, 樹齢は 1984 年の時点 で 13 年生であった。興津早生園は植栽本数が 40 樹, 樹 蹂は 1984 年の時点で 12 年生であり，このほ場はチャ; キイロアザミウマに対する.防除を例年 4〜5 回行ってい る。調査ほ場の全樹を調査樹とし，1樹につきミカン樹 の赤道部に着果する 20 果を選び，果実上に存在するチ ヤノキイロアザミウマを成虫, 幼虫別に見取り調查し た。調査期間は 1984 年が 5〜 10 月, 1985 年が 5 9 月， 1986 年が 6〜11 月であり, その間ほぼ 7 日間隔で調査 した。

温州ミカン果実に発現する被害は被害の発現し始める 時期によって 3 種に分けられる。まず, 最初に現れるの が，果実果梗部のへた周辺に見られる，灰白色のかすり 状の被害であり, 果梗部の被害と呼ぶ。次に, 果頂部に 円形状に同様の被害が現われ, 果頂部前期の被害と呼ぶ。 最後に, 果頂部に褐色の被青が発現し, 果頂部後期の被 害と呼んでいる。それらの被害別に 7 月下旬と 10 月下 旬の 2 回, 果梗部, 果頂部の被害を 1 樹めたり 20 果ず つ全樹について，それぞれ被害程度別に調査した。

1987 年および 1988 年には杉川温州みかん園 30a を 調査ほ場とした。植栽本数は 60 樹, 樹齢は 1987 年の時 点で 22 年生であり, チャノキイロアザミウマに対する 防除は行わなかった。このほ場を 3 区画に分割し， 1 区 あたり赤道部の果実 150 果を選び，1984１986 年と 同様に調査を行った。調査期間は両年ともに 5 月から 10 月までであり, 調査間隔はほぼ7日であった。な お，1988 年には果実を Fig. 1 のごとく 3 部位に区分し (pedicel : 果梗部, lateral part : 果侧部, stylar end : 果 頂部), 部位別に存在個体数を調査した。 5 年間を通し て，調查は午前 9 12 㭙に行った。

1987 年の果実被害調杳は前年までと同様年 2 回, 1988 年には 5 月から 10 月までほぼ 7 日間隔で行った。果実 の部位別被害は農林水産省農作物有害動植物発生予察事 業調査実施基準 (1986) に基ついて，3段階に分け，被 害度は次の式で求めた。

$$
\text { 被害度 }=\frac{\left(n_{1} \times 1\right)+\left(n_{2} \times 3\right)+\left(n_{3} \times 6\right)}{N \times 6}
$$

ここで $n_{1}, n_{2}, n_{3}$ はそれぞれ被害度 1 (果梗部はリン

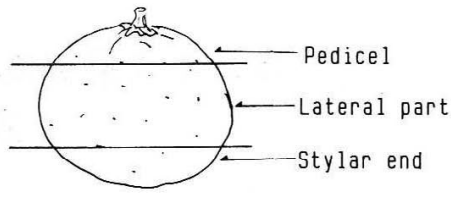

Fig. 1. Satsuma mandarin fruit surface divided for distinguishing position of $S$. dorsalis.

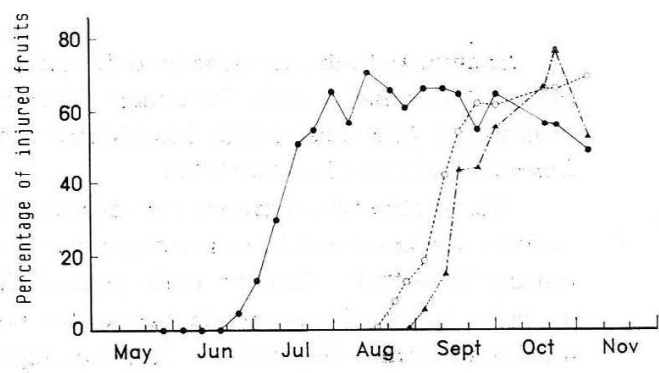

Fig. 2. Seasonal changes in intensity of fruit damage caused by $S$. dorsalis infestation in 1988 .

Damage to the pedicel, $0 \cdots \cdots \circ$ : Silver-scar damage to stylar end, and $\mathbf{A} \cdot \mathbf{- . - \mathbf { \Delta }}$ : Dark- brown scar damage to stylar end.

グ状の被害が果梗を中心に 1 周せず，かつ被害の軽いも の，果頂部は柱点を中心とした被害の直径が果実横径の 5 分の 1 程度のもの), 被害度 2 (果頂部はリング状の被 害が果梗を中心に 1 周しているものの, がく片に相似形 となった被害が軽いもの，果頂部は被害度１に記した被 害が果実横径の 2 分の 1 程度のもの), 被害度 3 (果梗 部はりング状の被害のみならず,ーがく片に相似形となっ た被害が出現しているもの, 果頂部は被害度 1 に記した 被害が果実横径の 2 分の 1 程度のbの) の果実数，Nは 調榃果実数である。

\section{結果}

\section{1. 温州ミカン果実の被害とその推移}

Fig. 2 は 1988 年の調查に打ける被害果摔の経時的変 化である。

果梗部の被害は 6 月上旬ごろから現れ始め, 8 月上旬 にピークになった。果頂部前期の被害は 8 月中旬ごろか ら現れ始め, 最初急激に増加した後, ゆるやかに増加 し，9月中旬ごろピークとなった。果頂部後期の被害は 8 月ト旬ごろから現れ始め, 最初の 2 週間は他の被害と 同様, 急激に增加し, その後 10 月下旬まで微增した。

\section{2. 果実上のアザミウマ存在部位の時期的変化}

1988 年のデータから, 果実の部位別 (Fig. 1) Kアザ 


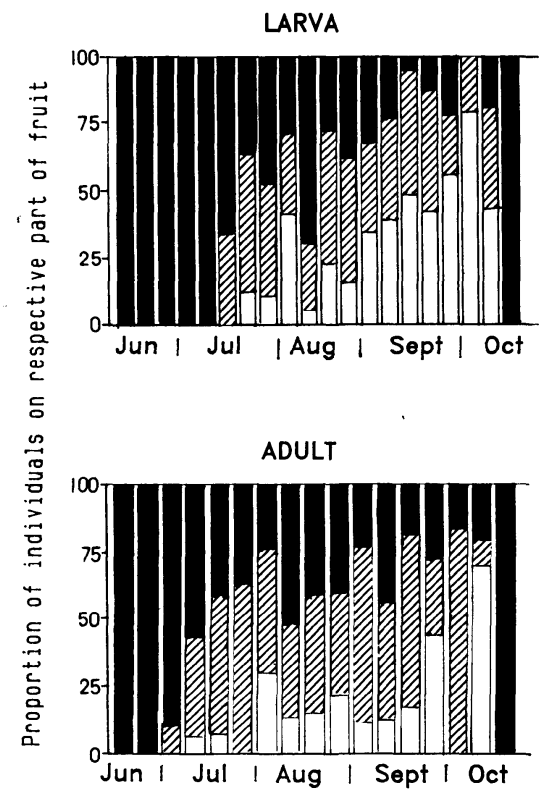

Fig. 3. Seasonal changes in location of $S$. dorsalis larvae (upper) and adults (lower) on parts of fruits in 1988. -... Pedicel, $\overline{I / I / I}$ : Lateral part and $\square$ : Stylar end.

ミウマ幼虫および成虫の存在割合を計算し，Fig. 3 を得 た。

成虫は 6 月下旬まで果梗部の久から発見されたが，7 月上旬から果側部に認められ始め，その割合はしだいに 高くなった。7 月中旬ごろからは果頂部に認められるよ らになり，多少ふれがあるものの，その割合はしだいに 高くなった。果了部での存在割合は果側部よりも低かっ た。

幼虫が果側部および果頂部に認められたのは成虫より も約 2 週間遅かった。それ以後の果梗部に特ける幼虫の 存在割合は成虫とほぼ同程度であったが，果頂部では幼 虫のほうが成虫よりも高い割合で推移した。

\section{3. 果実上のアザミウマの存在薮と被害との関係}

果実の部位により被害の発現時期が Fig. 2 のごとく 異なることから, 部位別の加害期間を区分し, 存在虫数 と被害の関係を解析した。

果梗部の被害果率が 7 月下旬からほぼ横ばいになった こと,ならびに，アザミウマの加害後果実の肥大に伴っ て被害が発現することから，果梗部の被害を引き起こす 加害期間を，6月上旬のアザミウマが果実上に見られ始 めるころから 7 月下旬とした。また, 果頂部前期では, 被害果率の上昇は 9 月中旬から下旬に鈍るが，その後も
わずかに上昇することから，8 月上旬から 9 月下旬を加 害期間とした。果頂部後期では被害果率の上昇時期が果 頂部前期の上昇時期とかなりの部分重なることと, 果皮 が褐色になる被害は果実の肥大停止期に起こり (高木, 1981), 灰白色の被害よりもアザミウマの密度が高くな ければ発現しないことから，防除上は果頂部前期と同一 視して考えた。

1 調查につき果実上の存在個体数 (成虫・幼虫別) の 調査結果を 100 果実あたりの存在個体数に換算し, 得ら れた值を先に定めたそれぞれの被害の加害期間中合計し て累積観察虫数とした。また，それぞれの加害期間中， 100 果あたり虫数が最も高かった調查日の值を最高観察 虫数とした。それらと被害調査結果をTable 1 に示した。 この結果から，それぞれの加害時期に対応する累積ある いは最高観察虫数と被害度との関係を求め, Table 2 に 示した。果梗部の被害は成虫・幼虫ともに高い相関が認 められた。果頂部の被害は成虫のほらがやや高い相関が 認められたが，果梗部の被害とは異なり，有意ではなか った。

最高観察虫数と累積観察虫数との関係を求めると, 果 梗部の加害期間に扮ける幼虫では $r=0.9950(p<0.01)$, 成虫では $r=0.9675(p<0.01)$ となり, 果頂部の加害 期間に打ける幼虫では $r=0.9668(p<0.01)$, 成虫では $r=0.8256(p<0.01)$ となり，いずれの場合も高い相関 が認められた。幼虫の最高観察虫数と被害度との関係は Table 2 に示したように，果梗部では最も高い相関が認 められた。

平均的なミカン農家の許容被害水準は収穫果実に打い て被害度が 10 以下とされている。これ以下に被害を抑 えるためには, 幼虫の最高観察虫数 $(x)$ と被害度 $(y)$ と の関係から求めた回㷌式, $y=1.96+0.65 x\left(r^{2}=0.8890\right.$, $p<0.01)$ によって, 果梗部の加害期間に 100 果あたりの 幼虫数が，12 頭で防除すればよいことになる。

果頂部に抢ける最高観察虫数と被害との関係は幼虫, 成虫拉よび成・幼虫の合計虫数ともに有意ではなかっ た。とくに，成虫では累積観察虫数と被害との関係より 相関係数はかなり低かった。

4. 果実上の個体数の樹間および果実間における分布 様式と必要サンプル数

IWAO (1968) の示した平均密度と平均混み合い度との 関係を樹間および果実間，また，幼虫と成虫についてプ ロットしたのが Fig. 4 である。

成虫の樹間之果実間における回帰式の $y$ 軸切片すなわ ち基本集合度指数 $(\alpha)$ はそれぞれ $0.20,0.11$ と 0 より 
Table 1. Densities of $S$. dorsalis on fruit and fruit damage in satsuma mandarin groves, Shimizu, Shizuoka in 1984-1988

\begin{tabular}{|c|c|c|c|c|c|c|c|c|c|c|c|}
\hline \multirow{3}{*}{ Field No ${ }^{\mathrm{f}}$} & \multirow{3}{*}{ Year } & \multicolumn{5}{|c|}{ Pedicel damage $^{\mathrm{a}}$} & \multicolumn{5}{|c|}{ Stylar end damage } \\
\hline & & \multicolumn{2}{|c|}{ Max. density ${ }^{c}$} & \multicolumn{2}{|c|}{ Cumulative $^{\mathrm{d}}$} & \multirow{2}{*}{ Damage index ${ }^{e}$} & \multicolumn{2}{|c|}{ Max. density ${ }^{\mathrm{e}}$} & \multicolumn{2}{|c|}{ Cumulative $^{\mathrm{d}}$} & \multirow{2}{*}{ Damage index } \\
\hline & & Larva & Adult & Larva & Adult & & Larva & Adult & Larva & Adult & \\
\hline \multirow{3}{*}{ No. 1} & 1984 & 2.5 & 1.4 & 3.1 & 4.3 & 2.5 & 3.6 & 4.9 & 11.5 & 23.4 & 8.1 \\
\hline & 1985 & 0.9 & 0.4 & 2.9 & 7.9 & 3.9 & 1.6 & 1.0 & 3.9 & 7.9 & 11.1 \\
\hline & 1986 & 5.0 & 3.3 & 6.5 & 9.8 & 2.9 & 2.5 & 4.0 & 6.0 & 16.5 & 3.2 \\
\hline \multirow{3}{*}{ No. 2} & 1984 & 1.1 & 3.9 & 1.2 & 7.1 & 0.9 & 1.2 & 7.1 & 3.9 & 13.4 & 7.3 \\
\hline & 1985 & 0.5 & 0 & 1.0 & 0.5 & 3.3 & 24.8 & 19.4 & 36.1 & 72.1 & 5.0 \\
\hline & 1986 & 0.5 & 3.0 & 1.0 & 3.5 & 2.3 & 32.0 & 39.0 & 50.1 & 65.0 & 6.9 \\
\hline \multirow[t]{2}{*}{ No. $3-1$} & 1987 & 18.6 & 11.2 & 21.0 & 19.0 & 13.9 & 29.4 & 404.0 & 75.2 & 555.4 & 9.6 \\
\hline & 1988 & 34.0 & 26.6 & 37.2 & 49.8 & 17.8 & 38.4 & 64.8 & 146.6 & 315.4 & 12.2 \\
\hline \multirow[t]{2}{*}{ No. $3-2$} & 1987 & 27.2 & 27.4 & 30.2 & 39.2 & 21.8 & 20.6 & 73.6 & 78.8 & 245.6 & 13.5 \\
\hline & 1988 & 28.8 & 26.4 & 36.8 & 51.2 & 26.6 & 404.0 & 100.0 & 480.2 & 487.8 & 50.1 \\
\hline \multirow[t]{2}{*}{ No. $3-3$} & 1987 & 2.8 & 0.5 & 5.0 & 1.0 & 4.8 & 2.0 & 3.0 & 5.5 & 12.5 & 1.0 \\
\hline & 1988 & 7.4 & 6.6 & 9.2 & 11.9 & 6.8 & 14.0 & 9.2 & 41.7 & 74.7 & 3.9 \\
\hline
\end{tabular}

a Damage to pedicel of fruit caused by thrips infestation in June and July. The period was estimated by the seasonal change of the damage (Fig. 2).

b Silver-scar damage to stylar end of fruit caused by thrips infestation in August and September. The period was estimated by the same source as above.

c Maximum value of mean densities per 100 fruits during infestation period of respective part of fruit.

d Accumulation of densities per 100 fruits during infestation period of respective part of fruit.

- Damage $=\left\{\left(n_{1} \times 1\right)+\left(n_{2} \times 3\right)+\left(n_{3} \times 6\right)\right\} /(N \times 6)$, where $n_{1}, n_{2}$, and $n_{3}$ are damage grades. $N$ is the number of fruits sampled.

f Unsprayed fields except for No. 2 which was treated with four or five pesticide applications per year.

Table 2. Correlation coefficients between number of $S$. dorsalis on fruits and damage index calculated from data in 1984-1988

\begin{tabular}{llcc} 
& Stage & $\begin{array}{c}\text { Pedicel } \\
\text { damage }\end{array}$ & $\begin{array}{c}\text { Stylar end } \\
\text { damage }\end{array}$ \\
\hline $\begin{array}{c}\text { Cumulative } \\
\text { number }\end{array}$ & $\begin{array}{l}\text { Adult } \\
\text { Larva }\end{array}$ & $0.9442^{* *}$ & $0.6871^{* *}$ \\
& $\begin{array}{l}\text { Adult } \\
\text { and larva }\end{array}$ & $0.9640^{* *}$ & $0.5869^{*}$ \\
& $\begin{array}{l}\text { Adult } \\
\text { Larva }\end{array}$ & $0.9310^{* *}$ & $0.6531^{*}$ \\
\hline \multirow{2}{*}{$\begin{array}{l}0.9430^{* *} \\
\text { Adult }\end{array}$} & $0.4025^{\mathrm{ns}}$ \\
& and larva & $0.9399^{* *}$ & $0.3124^{\mathrm{ns}}$ \\
\hline
\end{tabular}

a,b See Table 1.

ns $=$ not significant, $*=p<0.05, * *=p<0.01$

大きく，回帰式の傾きすなわち密度集合指数 $(\boldsymbol{\beta})$ は樹間 1.94, 果実間 1.37 と両者とも 1 より大きい值を示した ことから, 成虫は樹間, 果実間に招いて一定の平均値を もつ集団が集中分布していると見なされた。

幼虫の $\alpha$ は樹間で 0.39 と 0 より大きく, 果実間では - 0.11 とほぼ 0 に近く, $\beta$ は樹間が 5.62, 果実間が 5.13 となったことから, 成虫と同様, 樹間, 果実間において
集中分布していると見なすことができる。

幼虫と成虫を比較すると, 樹間・果実間ともに幼虫の 方が $\beta$ が大きく，密度が高くなるにしたがって集中度を 増す程度が大きいと見なされた。樹間と果実間を比較す ると幼虫・成虫ともに樹間のほうがわずかに $\beta$ が大きか った。

標本抽出を果実の単純ランダム抽出とした場合, 幼虫 調査の必要サンプル数 $\left(q_{D}\right)$ は次式で与えられる (IWAO and Kuno, 1968)。

$$
q_{D}=\frac{1}{D^{2}}\left(\frac{\alpha+1}{m}+\beta-1\right)
$$

ここで, $D$ は相対精度, $m$ は平均密度である。 $D$ を $0.1,0.2,0.3$ と変化させた場合の必要サンプル数は Fig. 5 で示したよらになった。この結果より $D=0.3$ と して要防除密度時の一つのほ場あたりの必要サンプル数 を計算すると, 果梗部の被害時期では要防除密度が 100 果あたり幼虫数 12 頭なので, 125 果となった。

また, 河野・杉野 (1958) の提唱した $p=1$ $\exp \left[-a m^{b}\right]$ (ここで, $p$ は存在頻度, $m$ は平均密度, $a$ ・ $b$ はパラメータ) に調査データをあてはめ, 幼虫の存在 頻度と密度との関係を求めた結果, 次式が得られた。 

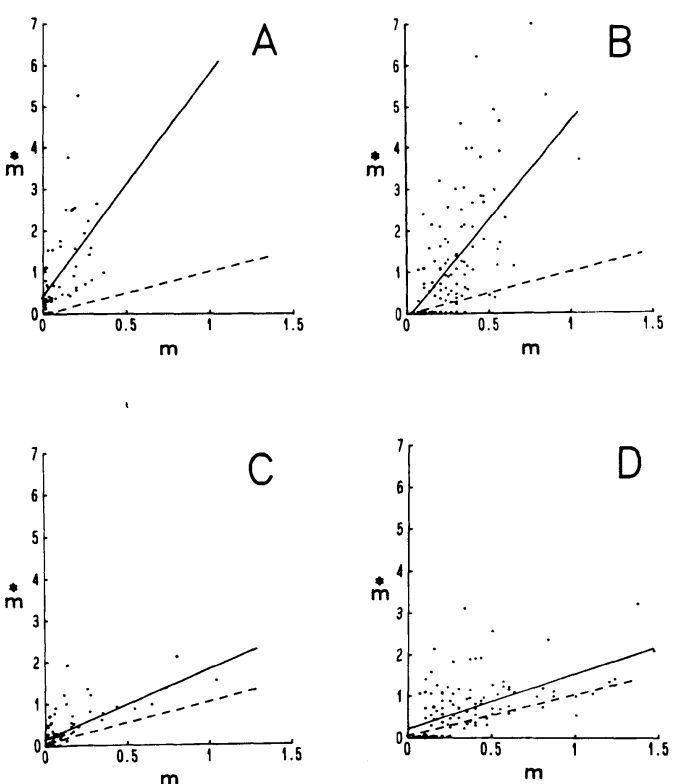

Fig. 4. Regression of mean crowding $(\stackrel{*}{*})$ to number of $S$. dorsalis per fruit $(m)$. (A): Between trees for larvae, $\stackrel{*}{m=0.39+5.62 m,} r^{2}=0.2954 \quad(p<0.01)$. (B): Within tree for larvae, $\stackrel{*}{m}=-0.11+5.13 m$, $r^{2}=0.4436 \quad(p<0.01)$. (C): Between trees for

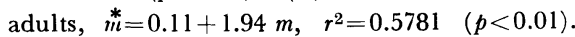
(D): Within tree for adults, $\stackrel{*}{m}=0.20+1.37 \mathrm{~m}$, $r^{2}=0.3215(p<0.01)$. Dotted lines indicate the regression for Poisson distributions.

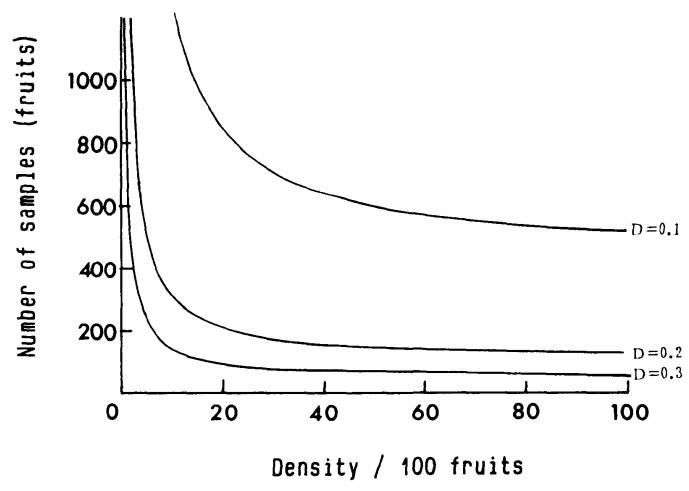

Fig. 5. Theoretical sample sizes for $0.1,0.2$, and 0.3 levels of precision after IWAO and Kuno (1968).

$$
\begin{gathered}
p=1-\exp \left[-0.5287 m^{0.8784}\right] \\
\left(r^{2}=0.9734, p<0.001\right)
\end{gathered}
$$

収穫期の被害度を 10 以下に抑兄るための要防除水準 である果梗部の加害期間の幼虫の最高観察虫数 12 頭を
前式に代入し，計算した結果，被害度を 10 以下に抑え るための要防除存在果率は果梗部の加害期間では $8.0 \%$ となった。

考察

チャノキイロアザミウマによる温州ミカン果実の被害 発現形態は時期的に異なる。今回の調査から，このこと が単に生息場所の時期的な变化に由来するのでないこと が明らかになった (Fig. 3)。果側部にはアザミウマが みられるのに被害が生じない。果側部がもはや細胞分裂 を行っていない部位であることから，加害を受けてから の補償作用によるとは考えにくい。したがって，果側部 の果皮表面はアザミウマが加害でさないほど硬いか，栄 養的に適さないため加害しないのではないかと考えられ る。

果梗部の加害時期には加害場所にがくと果皮の間とい う隠れ場所があるため，アザミウマはそこに集まり，果 実の他の部位には分布しないと考えられる。果頂部の加 害時期には良れ場所がないため，直射日光を避けるなど して果実上を徘徊し，果実の他の部位にも分布するもの と考えられる。また，果頂部前期の被害と果頂部後期の 被害の増加時期が重なるのは，果実の生育にばらつきが あるためと思われる。

WIESENBORN and MORSE (1986) は体内に取り込まれ た ${ }^{14} \mathrm{C}$ を定量することによって,アメリカのカンキッ害 虫であり，チャノキイロアザミウマと同属の S. citri の 発育ステージ別の摂食量を調査し，カンキツの被害は拈 もに 2 齢幼虫によると結論づけた。しかし，先に述べた ように，発現する被害は摂食量ではなく，摂食のために 破壊した細胞の数で決まる。現に発現した被害はチャ キイロアザミウマの場合, 成虫と幼虫との間に差がなか った (多々良, 未発表)。今回の調査に扣いて, 幼虫と成 虫の密度と被害との関係が果梗部では双方とも高い相関 があったことはうなずける (Table 2)。一方，果頂部に なると相関が低くなり，とくに成虫の累積観察虫数と被 害との関係は，幼虫の場合と同様，有意な関係が認めら れたにもかかわらず，成虫の最高観察虫数と被害とでは ほとんど関係が認められなかった。これは累積観察虫数 と被害との関係では, 成虫が産卵することによって，あ る程度幼虫の密度を反映することが前者の関係で相関が 高かった一因と考兄られる。果頂部が果梗部の場合より も相関が低かったのは，果頂部の加害時期にそこから見 いだされる成虫が少ないこと (Fig. 3)，8 月以降発生す るカンキッの夏芽, 秋芽と呼ばれる新芽が成虫の移動場 
所になることが要因と考兄られるが，さらに検討が必要 である。幼虫では，成虫よりも最高観察虫数と果頂部の 被害との相関が高かった。これは加害時期注果頂部より 見いだされる割合が成虫よりも多く(Fig. 3)，また，成 虫よりも移動が少ないためと考兄られる。しかし，果梗 部の場合よりも相関は低かった。果頂部への加害時期は 果梗部よりも長く，さまざまな要因がかかわってくる可 能性があるが，これらの要因について，今回の結果から は明らかにならなかった。

本研究のデータの解析に括いては, 防除園と無防除園 のデータを込みにして行った。ミカン園に括けるアザミ ウマの分布は, 農薬散布時の散布むら等によって, 変化 する可能性がある。しかし，無防除園であってもチャな ぞ周囲の増殖源の有無，あるいは増殖源に括ける薬剤散 布などのほ場条件，あるいは雨等の気象によってアザミ ウマの分布は変化する可能性があるだろう。モニタリン グを行うほ場は通常防除園であるので，複数の無防除ほ 場のデータとともに，防除の要素も組み入れた分布様式 の解析は現場での適用上重要であると考光られる。もち ろん，防除園であっても，防除の回数，防除からの経過 日数などによって分布は異なることが予想され，さらに 多くのデータの集積が必要である。

日本のカンキッ農家は, 多くの場合, 所有する 1 ほ場 の単位が小さく, しかも多くが分散しているのが常であ る。このため, 現場で行われている防除要否の決定に適 用する場合, 累積虫数で防除の要否を決定するのは煩雑 であり，実用性に乏しい。

農協あるいは農家が防除の判断のために調查を行う 際，煩雑な方法は敬遠され，もし欲のまま実行されたと しても間違いの生じる危険性が強い。今回の結果から， 最も確実な方法は, 果梗部の加害時期は幼虫と成虫の両 方, 果頂部の加害時期は幼虫の久でかつ樹と果実の 2 段 抽出で密度調查を行うことである。しかし，上記の理由 から，果実のみの無作為抽出，調查期間を通して幼虫の 又を調查対象としたほらが精度は劣るが実用性が高い。 また, 本種の幼虫は, 特に果梗部の加害時期, へたの下 に隠れていて正確な虫数を短時間に調査することは困難 である。そこで，果実上の個体数之存在果率には高い相 関が認められたことから, 存在果率を実際の調査時に採 用するのが最も簡便である。

今後, より簡便な方法として, トラップや数理モデル によるカンキッ園に括ける発生予察方法を確立する必要 があろう。
摘

要

チャノキイロアザミウマに対する防除カンキッ園，無 防除カンキッ園の 5 年間にわたる延べ 12 ほ場の調査デ 一タから，本種の果実に対する加害習性招よび果実上に 存在する個体数と被害との関係を解明し，要防除密度を 算出した。同時に，カンキッ園に招ける分布特性を明ら かにし，調査に必要な抽出果実数を求めた。

1）果実果梗部に生じる灰白色の被害は 6 月上旬に発 現し始め，8月上旬にピークとなった。果頂部に生じる 灰白色の被害は 8 月中旬に発現し始め, 9 月中旬にピー クとなった。同じく果頂部に生じる褐色の被害は 8 月下 旬ごろから現れ始め 10 月下旬まで増加した。

2）果梗部では加害時期とアザミウマの存在部位の場 所が一致したが，果頂部の加害時期は被害発生部位にい る虫が少なかった。成虫よりも幼虫のほうがそれぞれの 被害発生時期に被害発生部位にいる割合が高かった。

3）調査期間中の最高観察虫数と收穫期の被害度との 関係は，果梗部の加害時期では幼虫，成虫ともに有意な 正の相関関係が認められたが，果頂部の加害期間では有 意な関係が認められなかった。

4) 以上の関係より，果梗部に括ける收穫期の被害度 を 10 以下に抑えるための要防除水準は，6月上旬から 7 月下旬の期間では 100 果あたり幼虫数 12 頭と算出さ れた。また，幼虫の存在果率に換算すると，要防除水準 は果梗部の加害期間では $8.0 \%$ ，そのときの必要サンブ ル数は, 果実の単純ランダム抽出とし, 相対精度を 0.3 とした場合，調査ほ場あたり 125 果となった。

5）果実上の幼虫・成虫はともに樹間・果実間で集中 分布を示し，とくに成虫より幼虫，果実間より樹間で集 中分布の度合いが強かった。

\section{引用 文 献}

IwAo, S. (1968) A new regression method for analyzing the aggregation pattern of animal populations. Res. Popul. Ecol. 10: 1-20.

IwAo, S. and E. Kuno (1968) Use of the regression of mean crowding on mean density for estimating sample size and the transformation of data for the analysis of variance. Res. Popul. Ecol. 10: 210-214.

河野達郎・杉野多万司 (1958) ニカメイチュウの被害茎密度の 推定について. 応動昆 2: 184-187.

Mound, L.A. and J.M. Palmer (1981) Identification, distribution and host-plants of the species of Scirtothrips 
(Thysanoptera: Thripidae). Bull. Entomol. Res. 71: $467-479$.

村岡 実 (1988) チャノキイロアザミウマの寄主植物について. 佐賀果試研報 10: 91-102.

西野 操 (1972) チャノキイロアザミウマの永年性作物の被害 と対策, ミカン. 植物防疫 26: 432-434.

農林水産省農㫤園芸局植物防疫課 (1986) 農作物有害動植物発 生予察事業調査実施基準, pp. 142-143.

高木一夫 (1981) ミドリヒメヨコバイ類 Empoasca spp. チャノ

キイロアザミウマScirtothrips dorsalis HooD, ミカンハダ
= Panonychus citri (MCGREGOR), ミカンサビダニAculops pelekassi (KEIFER) のカンキツ果実上の食害痕. 果樹試報 D 3: $101-112$.

多々良明夫・古橋嘉一 (1986) チャノキイロアザミウマのカン キツ園に打将発生消長. 関西病研 27: 52 .

Wiesenborn, W.D. and J.G. Morse (1986) Feeding rate of Scirtothrips citri (Moulton) (Thysanoptera: Thripidae) as influenced by life stage and temperature. Environ. Entomol. 15: 763-766. 